\title{
Spreading Correct View of Love in College Chinese Teaching ----Exemplified by Song Ci Poems
}

\author{
Zhang Yilei, Xin Feng \\ Jingdezhen Ceramic Institute, Jingdezhen City, Jiangxi Province, China 333403
}

Keywords: College Chinese; View of Love; Spreading; Song Ci Poem

\begin{abstract}
College students are energetic and idealistic; their mind and thought are becoming mature. Therefore, it is natural for college students to fall in love. However, some students may blindly pursue their love or lack of correct view of love. As a result, some students' love has resulted in tragedy. For his phenomenon, teachers majoring in Chinese should take advantage of Song $\mathrm{Ci}$ poems to instruct the students how to establish correct and positive view of love.

As China once ranked as one of the four ancient civilizations, Chinese literature is high regarded in the world, especially Song Ci poems which contain lots of love stories. In college, not only do students strive for rich knowledge, high education, and better future, they also wish for beautiful love. Although many students fall in love during college, they hardly understand the essence of love, and their love always ends up unhappy. Love is a never-ending legend, and in Song Ci poems, there are many classical love stories. The teacher of Chinese ought to make use of these love stories to spread correct view of love to college students.
\end{abstract}

\section{Sticking to personal independence in love}

First, take Lu You who was a famous poet in South Song as an example. Lu You was known to most Chinese for his poems, but few learn about his love and tragic marriage. In his "Two Poems Created in Shenyuan Garden", he expresses his strong love for his wife Tang Wan who died forty years ago. Although he loved his wife deeply, he had to divorce her, because his wife was barren. In feudal system, it would be thought impiety not to have offspring. From Lu You's love story, we can see that personal independence is significant in love. If he had had the courage to fight against the feudal idea, he would have harvested his happy love and his love story would have had a happy ending.

Feudal society prevailed in China for more than a thousand years, so its influence can still have impact on Chinese. The feudal ideas, especially the idea to have offspring, are always the cause for inharmonious affection of a couple, even the cause for breakdown of a marriage. In modern Chinese life, although free love and free marriage are greatly advocated, in reality many young people's love is controlled by their parents; and the individuals in love cannot make their own resolution, feeling misery every day. If college students are to pursue love, they should take into account the level of family democracy which includes whether parents are accustomed to interfering with children's decisions, or whether the family has a strong tendency to have a male baby. They should also consider the family economics, and the housing conditions. If these issues are thought over beforehand, many family conflicts in marriage may be avoided. Another problem is whether to live with parents after marriage. If you have to, you must prepare to bear the disadvantage of lack of private space. If you are a female, you must be ready to equip yourself with the ability to handle the relationship between wife and mother-in-law. If you are a male, you must be qualified with the capacity to mediate such a relationship, and you have to be objective.

\section{Pursuing high-quality love}

In the poem "Immortal of the Magpie Bridge", Song poet Qin Guan writes "If love between both sides can last for age, why need they stay together night and day?" This poem is based on the Chinese love legend of Niu Lang and Zhi Nü, trying to illustrate his notion about the quality of love. In the love legend, Niu Lang and Zhi Nü can only meet once in a year, but their love keeps deep and 
long-standing. Although the ending of the love story is a tragedy and there is misery remaining in the sweethearts, the poet Qin Guan maintains that their love is as indestructible as gold. In real life, even though so many lovers stay night and day, they are faced with various crises to their affection; consequently, many of them break up. Though Niu Lang and Zhi Nü can merely date once a year, they possess high quality of love.

This legend is to caution the modern college students that they ought to go after the quality of love, rather than the quantity. The notion of love quality consists of four aspects. The first, the lovers should make progress in their love and know more about each other through each date, because dating is not aiming to kill time. The second, the lovers should fall deeply and sincerely in love only once in life. During dating, if one finds that the partner's personal independence, hobbies, and philosophy of life are the same as his, he should seriously take marriage into consideration. If it is the other way around, he should decidedly terminate the love, and do not show ambiguous hints. The third, one should be loyal to his sexual partner in life. Nevertheless, as people's notion about sex becomes less rigorous and casual, the sexual problem among college students turns more and more serious. Therefore, the teacher of Chinese is to take the responsibility of love and marriage education in class. The fourth, the more times one is in love, the lower quality of love he holds. To maintain love, one needs to pay much energy and finance. If he frequently changes his love partner, not only does it represent the failure of the former love, but it also erodes your spirit and takes negative influence over your view of love. Someone may wish to accumulate love experience by dating with as many lovers as possible, since they hope to come close to true love by this means; however, this idea shows no respect and responsibility for both his love partner and himself.

For college students, in order to obtain life-term love, they are not supposed to stay together day and night. If they spend most of their precious time on love, their study and future career are sure to be impacted, because everything to be accomplished requires time and price. College is merely the starting point of future career; if college students waste much time on managing love, the bases of both their study and career will not be steadily laid. In such a competitive society, they should be concerned more about career; if they cannot find a job after graduation, how can they continue to maintain their love?

\section{Keeping rational restriction to love}

Song poet Liu Yong, in his famous poem "Farewell in Autumn", expresses a male's emotions for separating from his female lover. The setting of the poem is that the man is leaving from his love, yet the punter keeps pressing him to get on the boat. As the two lovers are reluctant to separate from each other, they choke with sobs. Even if the poet is a male, he describes the departing scene vividly and movingly. Young and energetic college students will fall in love rapidly and deeply, but they seldom contemplate the possibility of their marriage after graduation; consequently, most lovers will break up upon graduation, leaving regret for their whole life. It is common sense that two lovers had better not live in separated areas, otherwise they may face all kinds of troubles involving work, life, children, etc. So at the beginning of college students' love, they should think far, including the place for their future jobs, the possibility for them to live in the same area, the similarity of their ideals for life, and so on. Only if they have thought twice about these issues will they make the best choice and finally find their true and life-long love.

Li Qingzhao, a famous female poet in Song Dynasty, is proficient at expressing females' feelings toward separations. In her poem "Sorrow of Separation", the heroine knows that his husband will go to his faraway post, so she feels miserable. The nearer the departing day draws, the more misery she bears. She even doesn't wash her face or comb her hair. With no passion for life, she is sleepy and tired all day long. Yet in the deep heart, she approves of her husband to work distantly. This poem serves as a good example for female college students, i.e. they should consider first the working demand and pursuit of males. Therefore, females should treat separations rationally and reasonably; taking good care of themselves is the best comfort and support for their faraway male lovers. In Li Qingzhao's another poem "Slow, Slow Tune", using a series of reduplicated words, she expresses the heroine's bitterness and misery after the death of her husband. And the heroine recalls 
the dribs and drabs together with her husband in the past life. From this poem, college students should learn that love needs not only strong passion but also rational restriction. They must not lose themselves in love.

\section{Conclusion}

In college life, love is sacred and fascinating. The college should equip students with correct view of love, so as to enable them to rationally choose their way and object of love. Marriage is the final fruit of love, so college students ought to set marriage as the goal of love; and college teachers of Chinese should spread correct view of love to students, to help them make clear their notion of love.

\section{References}

[1] Dong Yanping, Liu Qin. Cultivation of Love Notion through College Chinese Class[J]. Science Vision, 2013(21).

[2] Ni Jia. Love Education in Chinese Teaching[D]. Hunan Normal University, 2012.

[3] Lu Haiyun. Love Education in Secondary Vocational Chinese Teaching[J]. Education Teaching Forum,2013(17). 